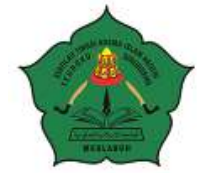

AT-TASYRI' Jurnal Ilmiah Prodi Muamalah

P-ISSN: 2085-2541, E-ISSN: 2715-7865

Volume 13, Nomor 2, Desember 2021

https://ejournal.staindirundeng.ac.id/index.php/Tasyri

\title{
KORELASI FILOSOFIS ANTARA RESTORATIVE JUSTICE DAN DIYAT DALAM SISTEM HUKUM PIDANA ISLAM
}

\author{
Mira Maulidar \\ UIN Ar-raniry Banda Aceh \\ nama@gmail.com
}

\begin{abstract}
Abstrak
Penyebutan restorative justice dalam Islam pada dasarnya sudah ada dalam hukum Islam, hal ini dapat dilihat dengan adanya konsep qishas diyat dan pemaafan dan tujuan dari keadilan restorasi agar pelaku dapat bertanggung jawab atas kerugian yang ditimbulkan olehnya terhadap korban dan masyarakat, lebih jauh penulis akan mengkaji berkaitan dengan titik temu atau korelasi secara filosofis antara restorative justice dan diyat dalam sistem hukum pidana Islam. Adapun Secara filosofis, restorative justice memiliki korelasi dengan konsep diyat dalam sistem hukum pidana Islam jika dihubungkan dengan salah satu tujuan pemidanaan Islam adalah al-istiadah (restoratif) sebagai metode merespons tindak pidana dengan melibatkan pihak-pihak yang bertikai dalam rangka memperbaiki kerusakan. konsep ini dapat dilihat dari adanya hukum diyat sebagi hukum pengganti qisas.
\end{abstract}

Kata Kunci: Korelasi, Filosofis, Restorative Justice, Diyat.

\begin{abstract}
Restorative justice in Islamic law basically already exists, this could be seen with the concept of qishash diyat and forgiveness. The purpose of restorative justice that the perpetrator can be held responsible for losses caused by him to the victim and the community. The researcher will studied about correlation of philoshopy between restorative justice and diyat in the Islamic criminal law system, if it is associated with one of the goals of Islamic punishment, namely alistiadah (restorative) as a method of responding to criminal acts by involving conflicting parties in order to repair the damage. This concept can be seen from the existence of diyat law as a substitute law for qisas.
\end{abstract}

Keywords: Correlation, Philosophy, Restorative Justice, Diyat.

\section{A. PENDAHULUAN}

Restorative justice merupakan filsafat, proses, ide, teori dan intervensi di mana menekankan untuk memperbaiki kerugian yang diakibatkan oleh perilaku kriminal. Konsep ini sangat bertolak belakang dengan mekanisme standar penanganan kejahatan yang dipandang sebagai pelanggaran yang dilakukan terhadap Negara. Restorative justice menemukan landasan dalam filosofi dasar dari sila keempat pancasila, dimana musyawarah menjadi prioritas dalam pengambilan keputusan, selain itu

penyelesaian perkaranya dilakukan dengan mediasi korban pelanggar, keadilan yang mampu menjawab kebutuhan yang sebenarnya dari korban, pelaku dan masyarakat.

Pendekatan keadilan restoratif hadir sebagai alternatif mekanisme penyelesaian perkara pidana diharapkan dapat menutupi kekurangan yang terdapat dalam sistem peradilan pidana tersebut dengan cara melibatkan partisipasi korban dan pelaku secara langsung. peradilan adat menjadi 
penting dalam kehidupan hukum nasional. Pendekatan keadilan restoratif dalam penerapan dan penegakan hukum, merupakan jembatan teoritis dan filosofis, untuk menjadikan nilai-nilai hukum yang hidup di masyarakat, sebagai dasar legitimasi pengembangan dan berfungsinya hukum, peradilan dan hakim adat, dalam distribusi keadilan. ${ }^{1}$

Restorative justice menempatkan nilai yang lebih tinggi dalam keterlibatan yang langsung dari para pihak. Korban mampu untuk mengembalikan unsur control sementara pelaku didorong untuk memikul tanggung jawab sebagai sebuah langkah dalam memperbaiki kesalahan yang disebabkan oleh tindak kejahatan dan dalam membangun sistem nilai sosialnya. Keterlibatan komunitas secara aktif memperkuat komunitas itu sendiri dan mengikat komunitas akan nilai-nilai untuk menghormati dan rasa saling mengasihi antar sesama. Peranan pemerintah secara substansial berkurang dalam memonopoli proses peradilan sekarang ini. Restorative justice membutuhkan usaha-usaha yang kooperatif dari komunitas dan pemerintah untuk menciptakan sebuah kondisi dimana korban dan pelaku dapat merekonsiliasikan konflik mereka dan memperbaiki luka-luka lama mereka. ${ }^{2}$

Restorative justice menekankan penyelesaian masalah antara para pihak dalam hubungan sosial dari pada menghadapkan pelaku dengan aparat pemerintah. Falsafah just peace principle diintegrasikan dengan the process of meeting, discussing and actively participating in the resolution of the criminal matter. Integrasi pelaku di satu sisi dan korban, masyarakat di lain sisi sebagai satu kesatuan mencari solusi serta kembalu pada pola hubungan baik dalam masyarakat.

Dunia international telah memberi guide lines on criminal justice tentang strategi pendekatan yang inovatif, komprehensif dan integral dengan meningkatkan penggunaan keadilan restoratif. Untuk mendesain kembali pelaksanaan peradilan yang lebih efektif, maka kongres PBB bisa menjadi salah satu inspirasi untuk mereformasi kebijakan peradilan.

Pendekatan restoratif sesungguhnya telah dikenal dan dipraktikkan di Indonesia dalam lingkup hukum adat Indonesia, seperti di Papua, bali, Toraja, Batak Minangkabau dan komunitas tradisional lain yang masih kuat memegang kebudayaan. Apabila terjadi suatu tindak pidana oleh seseorang, penyelesaian sengketa diselesaikan di komunitas adat secara internal tanpa melibatkan aparat negara. Ukuran keadilan bukan berdasarkan keadilan retributif berupa balas dendam (an eye for an eye) atau hukuman penjara, namun berdasarkan keinsafan dan pemaafan. (keadilan restoratif). Walaupun perbuatan pidana umum yang ditangani masyarakat sendiri bertentangan dengan hukum positif, terbukti mekanisme ini telah berhasil menjaga harmoni di tengah masyarakat. Keterlibatan aparat penegak hukum negara seringkali justru mempersulit dan memperuncing masalah. Jikalau dalam sistem peradilan pidana berdasarkan hukum barat setiap tindak pidana adalah pelanggaran hukum terhadap negara bukan orang perorangan secara pribadi maka dalam hukum adat suatu tindak pidana dapat dipandang

\footnotetext{
${ }^{1}$ Ahmad Ubbe, "Peradilan Adat Dan Keadilan Restoratif", artikel dalam Jurnal Recthsvinding, Vol. 2 No. 2, Agustus 2013, hlm. 161

${ }^{2}$ Daniel W. Van Ness, Restorative Justce and International Human Rights, Restorative Justice, International Perspektif Edited by Burt Galaway and Joe Hudson, (Kugler Publications, Amsterdam, The Netherland (Elsam 2005, Position Paper Advokasi, RUU KUHP Seri 3:11:12.
} 
sebagai suatu pelanggaran terhadap orang perorangan, suatu pelanggaran terhadap suatu golongan keluarga atau suatu pelanggaran terhadap suatu desa, sehingga mereka masing-masing berhak untuk mengurusnya. ${ }^{3}$

Konsep keadilan restorasi ini sebenarnya juga sudah terdapat dalam core philosopy bangsa Indonesia yaitu Pancasila sebagai sumber nilai dalam sistem hukum di Indonesia. Dalam sila ke 4 pancasila "kerakyatan yang dipimpin oleh hikmat kebijaksanaand alam permusyawaratan perwakilan" terdapat falsafah permusyawaratan yang mengutamakan musyawarah dalam setiap keputusan dan keputusan yang diambil harus dapat dipertanggungjawabkan secara moral kepada Tuhan yang Maha Esa, menjunjung tinggi harkat dan martabat manusia, nilai-nilai kebenaran dan keadilan mengutamakan persatuan demi kepentingan bersama. ${ }^{4}$

Sial ke-4 ini mengajarkan kita bahwa musyawarah menjadi pilihan untuk mengambil sebuah keputusan, dimana musyawarah yang diliputi semangat kekeluargaan, sehingga jika di breakdown falsafah musyawarah mengandung 5 (lima) prinsip sebagai berikut. Pertama, conferencing (bertemu untuk saling mendengar dan mengungkapkan keinginan; kedua, search solution (mencari solusi atau titil temu atas masalah yang sedang dihadapi; Ketiga, reconciliation (berdamai dengan tanggungjawab masing-masing); keempat, repair (memperbaiki atas semua akibat yang timbul) dan kelima, circles (saling menunjang).

Prinsip-prinsip tersebut diatas sama halnya dengan kata kunci dalam restorative justice, sehingga secara ketatanegaraan restorative justice menemukan dasar pijakan dalam sila ke-4 Pancasila. Kaidah musyawarah dengan prinsip musyawarah untuk mufakat mengandung esensi experiencing justice. Hal ini sejalan dengan pemikiran Jarem Sawatsky yang menyatakan bahwa:

Need of victims, offenders and communities are central for restorative justice.justice is about participation. This has a huge implication for justice. If needs are central then justice is always ad hoc. Justice must respond and be experienced within a context. That means justice will look different and be arrived at differently dependent on the need, the culture, the history, the future and the people involved. ${ }^{5}$

Justice peace dalam keadilan restorasi ditempuh dengan restorative conferencing yaitu mempertemukan antara pelaku-korban dan masyarakat untuk mencari dan memutuskan cara yang terbaik untuk mengatasi akibat dari kejahatan, selain itu pertemuan juga dimaksudkan untuk memberi kesempatan korban menghadapi pelaku guna mengungkap perasaannya, menyampaikan, bahkan menanyakan langsung kepada pelaku, pelaku dapat meminta maaf dengan memperbaiki kerusakan atau kerugian akibat perbuatannya, memperbaiki kesalahan dan menyetujui ganti rugi keuangan atau melakukan pekerjaan pelayanan. ${ }^{6}$

Selain itu dalam konsep keadilan restorasi pemberian maaf merupakan dasar memperbaiki hubungan manusia, pelaku menyesali perbuatannya, berjanji tidak akan mengulanginya lagi dengan memberikan sejumlah ganti rugi bila diperlukan, hal ini

\footnotetext{
${ }^{3}$ Henny Saida Flora, Pendekatan Restorative Justice Dalam Penyelesaian Perkara Pidana Dalam Sistem Peradilan Pidana Di Indonesia, (Jurnal Law Pro Justitia Vol II No. 2 Juni 2017), hlm 51-52

${ }^{4}$ Jurnal Dinamika Hukum Vol. 12 No.3 September 2012

${ }^{5}$ Jarem Sawatsky, Restorative Value: where means and ends converge, restorative justice online journal. Vol. IX, 2010, http://www.restorativejustice.org/articlesdb/articles/3681, Manitoba, Canada, hlm 12

${ }^{6}$ Morris and Maxwell, Restorative or Community Conferencing, The IIRP, hlm 17
} 
tidak didapatkan dalam konsep keadilan retributif dan restitutif.

Syariat Islam menjadikan diyat sebagai hukuman pokok untuk tindak pidana pembunuhan dan penganiayaan yang serupa sengaja atau pembunuhan dan penganiayaan yang terjadi karena kesalahan. ${ }^{7}$ Secara umum diyat itu terbagi kepada dua bagian, yaitu diyat pembunuhan dan diyat penganiayaan. Diyat pembunuhan diwajibkan terhadap pelaku pembunuhan, sedangkan diyat penganiayaan diwajibkan terhadap pelaku penganiayaan.

Hukum yang telah ditetapkan oleh Allah Swt terhadap pembunuhan adalah qishash. Namun ahli waris mempunyai hak untuk memilih dilaksanakannya qishash atau memberi maaf dengan menerima sejumlah diyat. Memberi maaf dengan pembayaran diyat, merupakan kemudahan dan rahmat dari Allah, yang dalam hal ini ada keluasan dan tidak memberatkan salah satu pihak. Barang siapa dengan sengaja melakukan pembunuhan terhadap seseorang sehingga ia mati sebelum menyelesaikan diyatnya, maka baginya siksa yang pedih, baik berupa pembalasan di dunia dengan dibunuh atau disiksa di akhirat dengan azab yang pedih.

Terhadap pelaku pembunuhan secara tidak sengaja diwajibkan baginya memerdekakan seorang hamba. Karena ia telah meniadakan jiwa seorang mukmin, maka sebagai kifaratnya adalah membayar denda. Atau membayar sejumlah diyat kepada keluarga korban, kecuali jika mereka (keluarga korban) dengan kerelaannya menggugurkan kewajiban membayar diyat itu, maka lepaslah si pelaku dari semua ancaman hukuman. ${ }^{8}$

\section{B. KAJIAN PUSTAKA}

Diyat secara etimologi adalah sesuatu berupa harta yang wajib dikeluarkan karena membunuh atau melukai seseorang, ${ }^{9}$ Menurut Kamus Besar Bahasa Indonesia, "diyat" adalah denda (berupa uang atau barang) yang harus dibayar karena melukai atau membunuh. 10 Diyat merupakan harta pengganti jiwa atau anggota tubuh, yakni sebagai ganti rugi yang diberikan oleh seorang pelaku tindak pidana kepada korban atau ahli warisnya karena suatu tindak pidana pembunuhan atau kejahatan terhadap anggota badan seseorang. ${ }^{11}$

Diyat adalah sejumlah uang atau harta yang harus dibayar oleh pelaku atau terpidana sebagai denda karena kematian atau kehilangan fungsi anggota badan lainnya, diyat ini merupakan pengganti daripada qishas atas pembunuhan sengaja atau tindak pidana yang dilakukan oleh seseorang namun dikarenakan adanya pemaafan dari pihak korban atau wali korban maka diganti dengan diyat. Kemudian "diyat" ini diberikan kepada korban atau ahli waris korban dengan jumlah yang sesuai dengan ketentuan yang telah ditetapkan oleh syari'at. Dengan demikian, sudah sepantasnya diyat merupakan sebuah sanksi yang sangat penting dan sangat manusiawi, karena di dalamnya mengandung nilai-nilai keadilan bagi keluarga korban yang dibunuh atau dilukai khususnya dan menjunjung tinggi harkat dan martabat manusia secara umum. ${ }^{12}$

\footnotetext{
${ }^{7}$ Abdul Qadir Audah, At-tashri’ Al-Jinai’ Al-Islami, Jilid. 2, Dar Al-Katib AlArabi, t.th., Bairut, hlm. 668

${ }^{8}$ As-Syafi'i, al-Umm,(Mesir: Dar al-Azhariyah, Tt),hlm 120

${ }^{9}$ Louit Ma'luf, Kamus al-Munjid, Darul Al-Masyriq, Beirut Libanon, 1973, hlm. 894.

${ }^{10}$ Depdikbud, Kamus Besar Bahasa Indonesia, Balai Pustaka, Jakarta, 1990, hlm. 156.

${ }^{11}$ Mohd Din, Stimulasi Pembangunan Hukum Pidana Nasional, Dari Aceh Untuk Indonesia, UNPAD PRESS, Bandung, 2009, hlm. 62.

${ }^{12}$ Muhammad Ihsan, Diyat Sebagai Pengganti Qishas Pada Jarimah Pembunuhan Sebab Pemaafan, (Jurnal: LEGALITE, Vol. I. No. 20, 2016, hlm 89
} 
Teori restorative justice merupakan reaksi yang timbul terhadap teori retributive justice yang berorientasi terhadap pembalasan dan teori neo-klasik yang berorientasi pada kesetaraan sanksi pidana dan sanksi tindakan. Dalam teori retributif, sanksi pidana berorientasi pada ide "mengapa diadakan pemidanaan". Dalam hal ini sanksi pidana lebih ditekankan pada unsur pembalasan (pengimbalan) yang bersifat reaktif terhadap suatu kejahatan atau pelanggaran. Sanksi ini dianggap sebagai penderitaan yang sengaja dibebankan kepada seorang pelanggar, sebagaimana yang dikemukakan oleh J.E. Jonkers bahwa sanksi pidana dititikberatkan pada pidana yang diterapkan untuk kejahatan yang dilakukan. Sedangkan sanksi tindakan bersumber pada ide "untuk apa diadakan pemidanaan itu". Jika dalam teori retributif sanksi pidana tertuju pada perbuatan salah seorang lewat melalui diberikan suatu penderitaan agar yang bersangkutan menjadi jera. Maka sanksi tindakan mengarah pada upaya diberikan pertolongan agar pelanggar yang bersangkutan berubah. ${ }^{13}$ Sanksi tindakan bertujuan lebih bersifat mendidik ${ }^{14}$ dan berorientasi pada perlindungan masyarakat. ${ }^{15}$

Restorative Justice merupakan peradilan yang menitikberatkan pada perbaikan atas kerugian yang disebabkan atau terkait dengan tindak pidana. Pola ini juga dilakukan melalui proses kooperatif yang melibatkan semua pihak (stake holders).
Berikut dikemukakan beberapa definisi restorative justice:

Menurut Howard Zehr, apabila dilihat dari lensa keadilan restorative, kejahatan adalah pelanggaran terhadap hubungan kemasyarakatan. Kejahatan menciptakan kewajiban untuk memberpabikinya. Keadilan melibatkan korban, pelaku, dan masyarakat dalam mencari solusi yang menawarkan perbaikan, rekonsiliasi dan jaminan. 16 Pendapat ini sejalan dengan sebagaimana yang dikemukakan oleh Burt Galaway dan Joe Hudson bahwa definisi keadilan restoratif meliputi beberapa unsur pokok: pertama kejahatan dipandang sebagai suatu konflik antara individu yang dapat mengakibatkan kerugian pada korban, masyarakat, maupun pelaku sendiri; kedua, tujuan dari proses peradilan pidana harus menciptakan perdamaian dalam masyarakat, dengan jalan perujukan semua pihak dan mengganti kerugian yang disebabkan oleh perselisihan tersebut; ketiga, proses peradilan pidana memudahkan peranan korban, pelaku, dan masyarakat untuk menemukan solusi dari konflik itu. ${ }^{17}$

Kevin I. Minor dan J.T. Morrison bahwa keadilan restoratif dapat digambarkan sebagai suatu tanggapan kepada perilaku kejahatan untuk memulihkan kerugian yang diderita oleh para korban kejahatan untuk memudahkan perdamaian antara pihak-pihak saling bertentangan. ${ }^{18}$ Definisi keadilan restoratif lebih rinci dikemukakan oleh Muladi dalam Kesimpulan Seminar nasional

${ }^{13}$ Muladi dan barda Nawawi Arief, hlm 4

${ }^{14}$ Utrecht, E, Rangkaian Sari Kuliah Umum Pidana II, (Surabaya: Tinta Mas, 1994), hlm. 360.

${ }^{15}$ Andi Hamzah, Sistem Pidana dan Pemidanaan Indonesia, dari Retribusi ke Reformasi, (Jakarta: Pradnya Paramita, 1986), hlm. 53.

${ }^{16}$ Howard Zehr, Changing lenses: a new focus for crime and justice, (Waterloo: Herald Press, 1990), hlm. 181.

${ }^{17}$ Ibid.

${ }^{18}$ Kevin Monor dan J.T. Morrison, A Theoritical Study and Critique of Restorative Justice, in Burt Galaway and Joe Hudson, eds, Restorative Justice: Internatiional Perspectives, (Monsey, New York: Ceimical Justice-Press and Kugler Publications, 1996), hlm. 117. 
HUT Ikatan Hakim Indonesia (IKAHI) ke-59 bahwa keadilan restoratif merupakan suatu pendekatan terhadap keadilan atas dasar falsafah dan nilai-nilai tanggungjawab, keterbukaan, kepercayaan, harapan, penyembuhan dan inclusiveness dan berdampak pada pengambilan keputusan kebiajakan sistem peradilan dan praktisi hukum di seluruh dunia dan menjanjikan hal positif ke depan berupa sistem keadilan untuk mengatasi konflik akibat kejahatan dan hukum yang dapat terlaksana apabila fokus perhatian diarahkan pada kerugian akibat tindak pidana, keprihatinan yang sama dan komitmen untuk melibatkan pelaku dan korban, mendorong pelaku untuk bertanggungjawab, kesempatan untuk dialog antara pelaku dan korban, melibatkan masyarakat terdampak kejahatan dalam proses retroaktif, mendorong kerjasama dan reintegrasi. ${ }^{19}$

Berdasarkan beberapa definisi di atas, restorative justice dapat diartikan sebagai salah satu alternatif atau metode lain dari peradilan pidana dengan mengedepankan pendekatan integrasi pelaku di satu sisi dan korban atau masyarakat di sisi lain sebagai satu kesatuan untuk mencari solusi serta kembali pada pola hubungan baik dalam masyarakat. Kata kunci dari restorative justice adalah empowerment. 20 Empowerment ini merupakan inti dari restoratif (the heart of the restorative ideology), oleh karena ini keberhasilan restorative justice ditentukan oleh empowerment ini ${ }^{21}$ Dalam konsep tradisional hukum pidana Indonesia, korban diharapkan untuk tetap diam, meneriam dan tidak ikut campur dalam proses pidana. Ide restorative justice secara fundamental mengatur kembali peran korban yang semulanya pasif hanya menunggu dan melihat bagaimana sistem pidana mengangani pelaku kejahatan, diberdayakan sehingga korban mempunyai hak pribadi untuk berpartisipasi dalam proses pidana.

\section{DATA DAN METODOLOGI}

Jenis penelitian hukum terdiri dari penelitian hukum normatif yang dilakukan dengan cara meneliti bahan pustaka yang merupakan data skunder (penelitian kepustakaan) dan penelitian hukum sosiologis atau empiris terutama meneliti data primer. ${ }^{22}$ Untuk menjawab permasalahan yang telah dirumuskan dalam penelitian ini digunakan metode penelitian hukum normatif (yuridis normatif). Penelitian hukum normatif (yuridis normatif) adalah metode penelitian hukum yang dilakukan dengan meneliti bahan pustaka atau data sekunder. ${ }^{23}$

Penulisan ini menggunakan penelitian hukum normatif, dimana hukum menjadi bahan dasar analisis, selain itu bahan hukum juga didasari atas peraturan perundangundangan, doktrin, maupun jurnal-jurnal yang

\footnotetext{
${ }^{19}$ Kesimpulan Seminar Nasional HUT Ikatan Hakim Indonesia (IKAHI) ke-59 dengan tema "Restorative Justice dalam Hukum Pidana Indonesia", Jakarta, 25 April 2012.

${ }^{20}$ Empowerment tersebut berkaitan dengan pihak-pihak dalam perkara pidana yang meliputi korban, pelaku dan masyarakat. Intinya, empowerment atau pemberdayaan dalam konteks restorative justice adalah proses pertemuan dalam hal antara pelaku dan korban atau masyarakat untuk membahas dan secara aktif berpartisipasi dalam penyelesaian masalah pidana (resolution of the criminal matter). Hal tersebut merupakan alternative atau pilihan lain dari pengaruh respon terhadap kejehatan.

${ }^{21}$ C. Barton, Empowerment and retribution in Criminal Justice. In: H. Strang, J. Braitwaite (eds), "Restorative Justice: Philosophy to Practice". Journal Temida Mart 2011. Aldershot: Ashgate/Dartmouth, hlm. 55-76.

${ }^{22}$ Sutrisno Hadi, Metode Research, (Yogyakarta: ANDI, 2000), hlm. 27

${ }^{23}$ Soerjono Soekanto dan Sri Mamudji, Penelitian Hukum Normatif (Suatu Tinjauan Singkat), (Jakarta: Rajawali Pers, 2001), hlm. 13-14.
} 
berkaitan dengan masalah Restorative Justice.

Pengumpulan bahan hukum yaitu Bahan hukum primer adalah bahan hukum yang bersifat autoritatif yaitu mempunyai otoritas

Bahan hukum sekunder merupakan bahan yang mempertegas analisa dari sisi asas-asas hukum, prinsip-prinsip hukum terhadap kaidah-kaidah hukum dari bahan hukum primer dengan didukung pula penguatan argumentasi hukum berdasarkan pendapat-pendapat dari para ahli hukum terkait dengan isu hukum, yang bersumber pada referensi dari karya-karya ilmiah maupun hasil laporan penelitian, jurnal-jurnal hukum yang mempunyai relevansi dengan permasalahan, sehingga didapat telaah yan bersifat komprehensif. Kegunaan bahan hukum sekunder adalah memberikan kepada peneliti semacam petunjuk kearah mana peneliti akan melangkah ${ }^{24}$.

Bahan hukum tersier merupakan bahan hukum yang memberikan petunjuk atau penjelasan kepada bahan hukum sekunder dan bahan hukum primer berupa kamus hukum, kamus umum dan ensiklopedia yang berkaitan dengan pokok permasalahan yang diangkat.

Metode analisis data yang digunakan penulis dalam penulisan ini adalah:

a. Content analisys (analisis isi), yaitu metodelogi penelitian yang memanfaatkan seperangkat prosedur untuk menarik kesimpulan yang shahih dari sebuah buku atau dokumen. ${ }^{25}$ Dalam hal ini adalah yang berkaitan dengan teori restorative justice. b. Metode preskriptif, yaitu suatu metode pemecahan masalah yang sudah teridentifikasi yang diperoleh secara normatif, lalu ditelaah secara sistematis, faktual dan akurat sesuai peraturan perundang-undangan yang berlaku. ${ }^{26}$

\section{HASIL DAN PEMBAHASAN}

Munculnya konsep restorative justice pada prinsipnya telah lebih dahulu diperkenalkan oleh fiqh jinayah ${ }^{27}$ sebagaimana ditegaskan dalam $\mathrm{Al}$ Qur'an Surah Al Baqarah ayat 178: "Maka barangsiapa yang mendapat suatu permaafan dari saudaranya, hendaklah yang memaafkan mengikuti dengan cara yang baik, dan hendaklah yang diberi maaf membayar diyat kepada yang memberi maaf dengan cara yang baik pula." Pengaturan lebih lanjut dapat dikaji melalui Al-Qur'an Surat An-Nisa ayat 92: "dan tidak layak bagi seorang mukmin membunuh seorang mukmin (yang lain), kecuali karena tersalah (tidak sengaja), dan Barangsiapa membunuh seorang mukmin karena tersalah (hendaklah) ia memerdekakan seorang hamba sahaya yang beriman serta membayar diat yang diserahkan kepada keluarganya (si terbunuh itu), kecuali jika mereka (keluarga terbunuh) bersedekah. jika ia (si terbunuh) dari kaum (kafir) yang ada Perjanjian (damai) antara mereka dengan kamu, Maka (hendaklah si pembunuh) membayar diat yang diserahkan kepada keluarganya (si terbunuh) serta memerdekakan hamba sahaya yang beriman. Barangsiapa yang tidak memperolehnya, Maka hendaklah ia (si pembunuh) berpuasa dua bulan berturut-turut untuk penerimaan

\footnotetext{
${ }^{24}$ Peter Mahmud Marzuki, Penelitian Hukum, (Jakarta: Kencana Prenada Media Group, 2005) hlm.155

${ }^{25}$ Soejono dan Abdurrahman, Metode Penelitian Suatu Pemikiran dan Penerapan, (Jakarta: Rineka Cipta, 1999), hlm. 13.

${ }^{26}$ Cholid Narbuko dan Abu Achmadi, Metode Penelitian, (Jakarta: Bumi Aksar, 2003), hlm. 44.

${ }^{27}$ Rocky Marbun, Konsep Diyat Sebagai Alternatif Pemidanaan Dalam Sistem Peradilan Pidana Untuk Mengatasi Fenomena Overcapacity Lembaga Pemasyarakatan, (Jurnal Hukum dan Peradilan, Volume 6 No. 2 , 2017) hlm. 202
} 
taubat dari pada Allah. dan adalah Allah Maha mengetahui lagi Maha Bijaksana.”

Asas restorative justice dalam Islam juga terlihat dalam ketentuan hukuman yang berlaku bagi pelaku pembunuhan. Tindak pidana pembunuhan dalam hukum Islam diberikan hukuman berupa qisas (dihukum mati), diyat (membayar denda), atau pemaafan dari keluarga korban. Ketiga bentuk pemidanaan tersebut bersifat alternatif bukan kumulatif, artinya jika sudah ditetapkan hukuman yang pertama, maka tidak dapat ditambah dengan hukuman yang kedua. Hal yang menarik adalah pilihan hukuman yang ketiga, yaitu adanya pemaafan dari keluarga korban.85 Pemaafan menjadi alasan penghapus pidana di dalam hukum Islam, hal mana tidak ditemukan di dalam hukum pidana di Indonesia. ${ }^{28}$

Dalam hal penuntutan, maka keluarga korban menjadi pihak yang berwenang dan berkepentingan dalam pengajuan penyelesaian perkara. Realitas ini menunjukkan bahwa tindak pidana dalam hukum Islam tidak masuk dalam kategori kejahatan umum secara mutlak, etapi juga masuk dalam kategori kejahatan privat. Dalam sistem hukum di Indonesia, jika pelanggaran tersebut masuk dalam ranah kejahatan publik, maka pemerintah (penegak hukum) berwenang menyelesaikannya. Termasuk dalam kategori ini adalah tindak pidana.Akan tetapi jika pelanggaran tersebut menyangkut hubungan orang per orang, maka para pihaklah yang berwenang menyelesaikannya. Termasuk dalam kelompok ini adalah hukum perdata.
Asas yang berlaku dalam hukum pidana Islam adalah pertanggung jawaban individu. Setiap pelaku kriminal harus mempertanggung jawabkan perilakunya, baik kepada Tuhan, korban, dan masyarakat. Prinsip inilah yang sejalan dengan restorative justice. $^{29}$

Hukum Islam sudah sejak lama mengakomodasi sifat tersebut. Terutama dalam jinayat atau hukum pidana Islam. Hukum pidana Islam pun mengenal adanya pemaafan yang dijelaskan sebagai salah satu poin penting dalam keadilan restoratif, khususnya dalam Jarimah Qisas/diyat yang merupakan jarimah terhadap manusia. ${ }^{30}$ Pema'afan dalam Qisas/Diyat, dapat dilakukan oleh Korban/ahli waris korban, karena telah menjadi hak perseorangan, penguasa tidak bisa memberikan ampunan terhadap pelaku dalam hal Kejahatan yang masuk dalam Qisas/Diyat.

Hukum Pidana Islam memandang jiwa manusia tidak hanya memiliki dimensi publik, namun juga dimensi keperdataan. Ruang lingkup hukum Islam tidak hanya menyangkut masalah pidana maupun perdata saja. Hukum Islam pun tidak membedakan secara tajam keduanya. Sistem ini berbeda dengan sistem hukum yang dianut sekarang ini, yang membedakan secara tajam antara hukum pidana dan perdata. Namun demikian efektifitas dari gambaran kortribusi hukum pidana Islam yang akan datang setidaknya memberikan pandangan lebih terhadap sistem hukum pidana nasional kedepannya. Prinsip nilai terhadap perlidungan jiwa dan keadilan

\footnotetext{
${ }^{28}$ Mutaz M. Qafisheh, "Restorative Justice in the Islamic Penal Law: A Contribution to the Global System", dalam International Journal of Criminal Justice Sciences, Vol 7 Issue 1 January - June 2012, hlm. 487.

${ }^{29}$ Susan C. Hascall, "Restorative Justice in Islam: Should Qisas Be Considered a Form of Restorative Justice?", dalam Berkeley Journal of Middle Eastern \& Islamic Law, Vol 4:1, 2011, hlm. 75

${ }^{30}$ Natangsa Subakti, Peradilan Restoratif dalam Bingkai Empiris, Teori dan Kebijakan, Yogyakarta: Genta Publishing, 2014
} 
sebenarnya telah tertuang terhadap sistem diversi.

Dalam konteks jinayat dan lebih khusus lagi persoalan pembunuhan, secara implisit menarik satu garis pembeda antara al'afwu dan Shulh dengan melihat arti mana inisiatif kompensasi itu muncul. Jikalau inisiatif pemberian kompensasi terhadap hukuman qisas tersebut berasal dari kedua belah pihak, maka itu dikatakan Shulh (perdamaian). Sedangkan jika inisiatif pemberian kompensasi itu hanya berasal dari satu pihak saja (tepatnya pihak korban), maka yang demikian itu masuk dalam kategori al'afwu (pemaafan).

Pembedaan antara Shulh dengan al'afwu tersebut dapat dikatakan hanya pada tataran konsep saja, sedangkan dalam praktek, sangat dimungkinkan terjadi persamaan teknis dalam pelaksanaan antara Shulh dan al'afwu sebagai satu metode penyelesaian suatu jarimah. Bahwa Shulh merupakan konsep perdamaian secara umum untuk masalah keluarga sampai pada masalah politik kenegaraan, dan mencakup pula dalam bidang hukum pidana dengan menekankan pada hasil kesepakatan bersama. Sedangkan al'afwu merupakan satu konsep penyelesaian perkara praktis berupa pemaafan dengan membebaskan pelaku dari tuntutan hukuman dengan konsekuensi korban memiliki pilihan untuk meminta diyat (kompensasi) atau tanpa kompensasi. ${ }^{31}$

Disinilah sebenarnya aspek penting dalam hukum pidana Islam, yaitu aspek restorative justice. Saat ini, di dunia hukum Barat sering dikeluhkan bahwa hukuman yang dijatuhkan oleh hakim tidak berpihak pada korban atau tidak berorientasi pada pemenuhan hak-hak korban. Dalam hukuman terhadap pembunuhan atau penganiayaan misalnya, peran korban di ambil oleh negara (polisi,jaksa dan hakim). Korban seringkali tidak dipedulikan dalam system dan proses peradilan pidana. Hukuman yang di jatuhkan seringkali tidak sesuai dengan rasa keadilan korban dan tidak membawa manfaat apa-apa bagi korban dan keluarganya.

Nilai-nilai restorative justice yang terdapat dalam hukum qisas antara lain terwujud dalam konsep: martabat manusia (human dignity), penghormatan (respect), dan keterlibatan masyarakat (community). ${ }^{32}$ Konsep martabat manusia terlihat jelas dalam filosofi hukum qisas sebagaimana tercantum dalam Q.S Al Baqarah ayat 179, yaitu penjagaan kehidupan manusia. Qisas harus ditegakkan untuk menjaga martabat manusia, yaitu menjaga kehidupan sesama. Tujuan qisas bukanlah untuk pembalasan dendam atas tindak pidana pembunuhan, tetapi menjaga hak hidup manusia sebagai hak asasi dari Tuhan. Perintah untuk mengambil diyat atau memaafkan pelaku merupakan bukti komitmen hukum qisas terhadap penjagaan martabat manusia. Kejahatan adalah pelanggaran terhadap hubungan kemanusiaan, yaitu hubungan interpersonal (pelaku dan korban) dan masyarakat. Korban dan masyarakat terluka dan perlu adanya pemulihan. Pemulihan inilah yang menjadi kunci bagi selesainya hukum sekaligus terjaganya martabat kemanusiaan.

Disyariatkannya diyat merupakan salah satu bentuk keringanan dari Allah SWT dari hukuman qishash atas suatu pembunuhan dengan sengaja, dan merupakan anugrah dan rahmat bagi umat manusia karena membebaskan dari pengaturan sebelumnya. Konsep diyat dalam Islam mirip dengan

${ }^{31}$ Mahrus Ali, Syarif Nurhidayat, Penyelesaian Pelanggaran HAM Berat In Court System \& Out Court System, Jakarta : Gratama Publishing, 2011, hlm 290.

${ }^{32}$ Susan C. Hascall, "Restorative Justice in Islam..., hlm. 75 
pidana pada pasal 10 KUHP, Berdasarkan Pasal 10 KUHP tersebut, sistem pemidanaan Indonesia memiliki instrumen yang sekilas mirip dengan diyat pada sistem hukum Islam. Perbedaannya adalah penerapan sistem pemidanaan di Indonesia, penerapan pidana denda bersifat kumulatif dengan pidana penjara. Dijatuhkannya vonis pidana denda tidak menghilangkan kewajiban pidana penjara. Sedangkan pada diyat baru dapat diterapkan ketika pihak yang merasa dirugikan memberikan kata maaf, maka pidana penjara tidak layak lagi untuk diterapkan kepada si pelaku tindak pidana.

Dalam hukum pidana Islam berlaku hukum qishash-diyat, hukuman bagi pelakunya adalah setimpal sesuai perbuatannya (qishash) dan ini sesuai rasa keadilan korban. Tetapi, perbuatan memaafkan dan perdamaian dari korban / keluarganya dipandang sebagai suatu yang lebih baik. Pihak pelaku bisa dijatuhi sanksi diyat (yaitu sejumlah harta tertentu untuk korban dan keluarganya). Hal ini membawa kebaikan bagi kedua belah pihak dan tidak ada lagi dendam antara kedua pihak itu. Pihak korban mendapat perbaikan dari sanksi yang dijatuhkan, serta ada peranan korban dalam sistem dan proses peradilan pidana.

Dengan terwujudnya berbagai orientasi tujuan pidana jika diterapkan melalui media lain (non penal), maka konsep Al-'afwu merupakan is justified atau dalam kata lain sanbat tepat untuk diterapkan. Dalam kaitkan dalam al-mas'uliyah fi-tasyri' $i$ al-jina'i terkait kekerasan seksual yang terjadi dalam ranah tangga yang dengan konsep pemaafan pidana (al-'afwu 'anil 'uqubah) dengan memberikan restitusi kepada korban dalam konsep tahkim atau mediasi pidana dirasa sudah mewakili konsep pemaafan dengan mengambil nilai- nilai kemaslahtan yaitu dar'ul mafasid muqoddam 'ala jalbi al-mashalih. Suatu kejahatan jika dilakukan mediasi pidana dengan cara kesepakatan pemaafan, maka harus ada proporsionalitas antara hak dan kewajiban yang harus dijalankan. ${ }^{33}$

Salah satu contoh putusan yang berkaitan dengan restorative justice dan diyat adalah pada kasus Pengadilan Negeri Kabanjahe, dimana Majelis Hakim yang memeriksa perkara perseteruan antara dua orang nenek-nenek yaitu Relta Boru Tarigan dengan Malem Kita Ginting. Dimana pihak Penyidik dan Jaksa Penuntut Umum mendakwa dan menuntut nenek Relta Boru Tarigan karena perbuatannya yang dapat diklasifikasikan sebagai penganiayaan dalam Pasal 351 ayat (1) KUHP, dengan tuntutan pidana 1 (satu) tahun penjara. Namun, Majelis Hakim berpendapat tuntutan tersebut terlalu berat sehingga Majelis Hakim lebih memilih menjatuhkan vonnis denda sebanyak Rp.2.500.000,- (dua juta lima ratus ribu rupiah) dengan subsider pidana kurungan selama 6 (enam) bulan apabila tidak membayar denda tersebut. ${ }^{34}$

Asas kerukunan atau rukun, menurut Soediman Kartodiprodjo merupakan alat pelengkapan bagi manusia selain raga, rasa, dan rasio dalam kehidupan berkelompok, dan tidak sebagai makhluk yang terpisah satu sama lain, dan kemudian karena sesuatu hal ingin hidup bersama berdasarkan asas kekeluargaan yang merupakan inti jiwa dari Pancasila. Dalam konteks asas kerukunan tersebut, maka hidup berkelompok itu baru ada manfaatnya kalau hidup dengan rukun, maka alat perlengkapan manusia ini hendak dinamakan unsur rukun dalam kehidupan manusia. Dengan demikian maka manusia itu terdiri dari empat unsur ini, yakni raga, rasa,

${ }^{33}$ M. Quarish Shihab, Tafsir Al-Mishbah; Pesan, Kesan dan Kreasi Al-Qur'an, Volume 1, Cet. Kedua, Lentera Hati, Jakarta, 2004, hlm 393.

${ }^{34}$ Rocky Marbun, Konsep Diyat Sebagai Alternatif...hlm 208 
rasio dan rukun. Dengan asas kerukunan inilah manusia akan mencapai kebahagiaan dalam kehidupannya. Kalau manusia Indonesia melihat tujuan hidup manusia adalah hidup bahagia seperti dibentangkan tadi, maka caranya mencari jalan untuk sampai hidup bahagia itu adalah dengan jalan mempergunakan alat-alat perlengkapan hidupnya sebaik-baiknya, yaitu cara musyawarah atau cara mufakat.

Cara musyawarah atau mufakat ini sebagai cara memperoleh kebahagiaan, yang mengandung arti diakui adanya atau mungkin adanya perbedaan antara manusia yang hidup berkelompok itu dalam mencari jalan yang menuju ke hidup bahagia tadi. Mengakui adanya perbedaan ini berarti mengakui adanya perbedaan dalam kepribadian masingmasing manusia yang berkelompok itu, dan dengan tidak menyatakan salah seorang; jadi pendapat salah seorang itu akan menguasai pendapat orang-orang lainnya, melainkan harus diadakan muyawarah atau mufakat. Maka menurut pemikiran Bangsa Indonesia itu kepribadian individu tidak saja diakui tetapi pula dilindungi. ${ }^{35}$

Musyawarah untuk mufakat dalam konsep restorative justice, menjadi hal yang sangat penting karena menghadirkan unsur pelaku, korban dan masyarakat, selain itu dalam musyawarah tersebut tentunya akan dibahas terkait dengan persoalan ganti rugi atau denda, hal ini juga sangat berkaitan erat dengan konsep diyat dalam sistem pemidanaan Islam yang juga mengutamakan musyawarah serta ganti rugi yang harus ditunaikan oleh pelaku.

Konsep penghormatan dalam hukum qisas terlihat pada kesetaraan kedudukan para pihak yang berkaitan dengan tindak pidana pembunuhan. Pelaku, korban, masyarakat adalah pihak-pihak yang berkepentingan dalam penyelesaian tindak pidana. Pelaku harus dimintai pertanggungjawaban, korban dan keluarganya harus diberdayakan, dan masyarakat harus berikan ruang partisipasi. Pada akhirnya, solusi hukum bagi tindak pidana pembunuhan adalah hasil mediasi dengan mempertemukan para pihak secara face to face. Secara psikologis hal ini mendukung bagi upaya pemulihan situasi sosial serta menjauhkan rasa balas dendam antara pelaku dengan keluarga korban. Pulihnya situasi ini adalah tujuan utama bagi penyelesaian tindak pidana di masyarakat.

Keterlibatan masyarakat juga memiliki arti penting bagi implementasi restorative justice. Masyarakat memiliki hak untuk mendapatkan kehidupan tenteram dan damai. Sehingga ketika terjadi tindak pidana, keterlibatan mereka dalam penyelesaiannya merupakan sebuah keniscayaan. Kejahatan, dalam perspektif restorative justice adalah problem antara pelaku dan korban dalam komunitas mereka. Oleh karena itu problem tersebut harus diselesaikan oleh semua anggota yang terlibat dan bukan oleh profesional hukum yang merupakan orang luar. ${ }^{36}$ Hal ini sekaligus memberikan tanggung jawab kepada masyarakat untuk menjaga ketertiban sosial di lingkungan masing masing sekaligus pembinaan terhadap warga masyarakat. ${ }^{37}$ Tujuan restorative justice adalah pemberdayaan korban, pelaku dan masyarakat. Masyarakat adalah pihak pertama yang diberdayakan untuk mengawasi konflik yang terjadi di kalangan mereka. Keterlibatan masyarakat dalam penyelesaian

\footnotetext{
${ }^{35}$ Achmad Suhardi Kartodiprodjo, et.al, Prof Mr. Soedirman Kartodiprodjo tentang Pancasila Sebagai Pandangan Hidup Bangsa Indonesia, (unpublished), Bandung/Jakarta: tanpa penerbit, 2009, hlm. 57-60.

${ }^{36}$ Paul Mc Cold, "Restorative Justice: The Role of the Community", Paper presented to the Academy of Criminal Justice Sciences Annual Conference, Boston, March 1995, diunduh dari http://www.iirp.edu/article_detail.php

${ }^{37}$ Paul Mc Cold, "Restorative Justice....
} 
tindak pidana akan menumbuhkan kesadaran serta ketaatan terhadap hukum, yang berpengaruh terhadap pencegahan munculnya tindak pidana.

Dalam salah satu tujuan pemidanaan Islam adalah Restoratif (al-isti'a_dah),yaitu sebagai metode merespons tindak pidana dengan melibatkan pihak-pihak yang bertikai dalam rangka memperbaiki kerusakan.konsep ini dapat dilihat dari adanya hukum diyat sebagi hukum pengganti qisas. ${ }^{38}$

\section{E. KESIMPULAN}

Secara filosofis, restorative justice memiliki korelasi dengan konsep diyat dalam sistem hukum pidana Islam jika dihubungkan dengan salah satu tujuan pemidanaan Islam adalah al-istiadah (restoratif) sebagai metode merespons tindak pidana dengan melibatkan pihak-pihak yang bertikai dalam rangka memperbaiki kerusakan. konsep ini dapat dilihat dari adanya hukum diyat sebagi hukum pengganti qisas.

\section{DAFTAR PUSTAKA}

Abdul Qadir Audah, (t.th), At-tashri' AlJinai' Al-Islami, Jilid. 2, Dar Al-Katib AlArabi, t.th., Bairut,

Achmad Suhardi Kartodiprodjo, (2009) et.al, Prof Mr. Soedirman Kartodiprodjo tentang Pancasila Sebagai Pandangan Hidup Bangsa Indonesia, (unpublished), Bandung/Jakarta: tanpa penerbit.

Ahmad Ubbe, (2013) "Peradilan Adat Dan Keadilan Restoratif", artikel dalam Jurnal Recthsvinding, Vol. 2 No. 2.

Andi Hamzah, (1986), Sistem Pidana dan Pemidanaan Indonesia, dari Retribusi ke Reformasi, Jakarta: Pradnya Paramita
As-Syafi'i, al-Umm, (tt) Mesir: Dar alAzhariyah,

C. Barton, (2011)Empowerment and retribution in Criminal Justice. In: H. Strang, J. Braitwaite (eds), "Restorative Justice: Philosophy to Practice". Journal Temida. Aldershot: Ashgate/Dartmouth.

Cholid Narbuko dan Abu Achmadi, (2003) Metode Penelitian, Jakarta: Bumi Aksar.

Daniel W. Van Ness, (2005), Restorative Justce and International Human Rights, Restorative Justice, International Perspektif Edited by Burt Galaway and Joe Hudson, (Kugler Publications, Amsterdam, The Netherland (Elsam, Position Paper Advokasi, RUU KUHP Seri 3:11:12.

Depdikbud, (1990), Kamus Besar Bahasa Indonesia, Balai Pustaka, Jakarta

Henny Saida Flora, (2017), Pendekatan Restorative Justice Dalam Penyelesaian Perkara Pidana Dalam Sistem Peradilan Pidana Di Indonesia, (Jurnal Law Pro Justitia Vol II No. 2

Howard Zehr, (1990), Changing lenses: a new focus for crime and justice, Waterloo: Herald Press.

Jarem Sawatsky, (2010) Restorative Value: where means and ends converge, restorative justice online journal.Vol.IX,http://www.restorativej ustice.org/articlesdb/articles/3681, Manitoba, Canada.

Kevin Monor dan J.T. Morrison, 1996, A Theoritical Study and Critique of Restorative Justice, in Burt Galaway and Joe Hudson, eds, Restorative Justice: Internatiional Perspectives, Monsey, New York: Ceimical JusticePress and Kugler Publications.

${ }^{38}$ Ocktoberrinsyah, "Tujuan Pemidanaan dalam Islam," In Right Jurnal Agama dan Hak Azazi Manusia Jurusan Hukum Pidana dan Tata Negera Islam, Vol.1 No. 1 (November 2011), hlm 30 
Louit Ma'luf, (1973) Kamus al-Munjid, Darul Al-Masyriq, Beirut Libanon,

M. Quarish Shihab, (2004), Tafsir AlMishbah; Pesan, Kesan dan Kreasi AlQur'an, Volume 1, Cet. Kedua, Lentera Hati, Jakarta.

Mahrus Ali, Syarif Nurhidayat, (2011), Penyelesaian Pelanggaran HAM Berat In Court System \& Out Court System, Jakarta : Gratama Publishing.

Mohd Din, (2009) Stimulasi Pembangunan Hukum Pidana Nasional, Dari Aceh Untuk Indonesia, UNPAD PRESS, Bandung

Muhammad Ihsan, (2016) Diyat Sebagai Pengganti Qishas Pada Jarimah Pembunuhan Sebab Pemaafan, (Jurnal: LEGALITE, Vol. I. No. 20

Mutaz M. Qafisheh, (2012), "Restorative Justice in the Islamic Penal Law: A Contribution to the Global System", dalam International Journal of Criminal Justice Sciences, Vol 7 Issue 1.

Natangsa Subakti, (2014) Peradilan Restoratif dalam Bingkai Empiris, Teori dan Kebijakan, Yogyakarta: Genta Publishing

Ocktoberrinsyah, (2011),"Tujuan Pemidanaan dalam Islam," In Right Jurnal Agama dan Hak Azazi Manusia Jurusan Hukum Pidana dan Tata Negera Islam, Vol.1 No. 1.
Paul Mc Cold, (1995) "Restorative Justice: The Role of the Community", Paper presented to the Academy of Criminal Justice Sciences Annual Conference, Boston, March 1995, diunduh dari http://www.iirp.edu/article_detail.php

Peter Mahmud Marzuki, (2005) Penelitian Hukum, (Jakarta: Kencana Prenada Media Group

Rocky Marbun, (2017) Konsep Diyat Sebagai Alternatif Pemidanaan Dalam Sistem Peradilan Pidana Untuk Mengatasi Fenomena Overcapacity Lembaga Pemasyarakatan, Jurnal Hukum dan Peradilan, Volume 6 No. 2.

Soejono dan Abdurrahman, (1999), Metode Penelitian Suatu Pemikiran dan Penerapan, Jakarta: Rineka Cipta,

Soerjono Soekanto dan Sri Mamudji, (2011) Penelitian Hukum Normatif (Suatu Tinjauan Singkat), Jakarta: Rajawali Pers.

Susan C. Hascall, (2011) "Restorative Justice in Islam: Should Qisas Be Considered a Form of Restorative Justice?", dalam Berkeley Journal of Middle Eastern \& Islamic Law, Vol 4:1

Sutrisno Hadi, 2000, Metode Research, Yogyakarta: ANDI.

Utrecht, E, (1994) Rangkaian Sari Kuliah Umum Pidana II, Surabaya: Tinta Mas. 